\title{
Population Dynamics of an Isolated Population of the Tropical Pyrrhocorid Bug, Melamphaus faber, Feeding on Seeds of Hydnocarpus Trees and the Specialist Predator, Raxa nishidai in Bogor, West Java, Indonesia
}

\author{
Takayoshi NISHIDA Laboratory of Insect Ecology, Graduate School of Agriculture, Kyoto University, \\ Kyoto 606-8502, Japan \\ Koji NAKAmura Laboratory of Ecology, Faculty of Science, Kanazawa University, Kanazawa 920- \\ 1192, Japan
}

Woro A. NoERdJITo Balai Penelitian dan Pengembangan Zoologi, Puslitbang Biologi, LIPI, Jl. Raya Bogor Jakarta Km 46, Cibinong 16911, Indonesia

\begin{abstract}
We studied dynamics of the isolated population of Melamphaus faber, a seed feeding pyrrhocorid bug and Raxa nishidai, its specialist predator, in the Bogor Botanic Gardens, West Java, Indonesia over 9 years intermittently from 1990 to 1998 . Throughout the entire census periods, reproduction was always observed. The density of $M$. faber was fairly stable among years, which was closely synchronized with the annual changes in the food availability but not with those in the predation level. These results suggest that availability of the food resource exclusively determines the population dynamics of $M$. faber. Although the number of fruits largely fluctuated year to year, the number of the fruits accumulated on the ground, the actual food resource level, was fairly constant, which may contribute to the stable population dynamics of $M$. faber. The density of $R$. nishidai was extremely low but persistent over the years in spite of the fact that the population was completely isolated from adjacent populations.
\end{abstract}

Key words: Population dynamics / Melamphaus faber / Raxa nishidai / prey-predator interaction / West Java

Detailed studies of insect population dynamics have been carried out mostly in temperate regions, while in tropics only a few are available except for studies on some serious agricultural or medical pests (Wolda, 1988; Young, 1982). The most striking difference of tropics from temperate regions is the absence of cold season when most insects cease their activities. Tropical environments were once, and are sometimes still, regarded as continuously warm and aseasonal so that insect activities last all the year round and generations overlap largely, particularly in tropical rain forests (Young, 1982). However, it has been gradually recognized that even insects living in tropical rain forests fluctuate the densities largely, and the generation-like cycles are often remarkable in spite of stable precipitation and temperature (Wolda, 1988; Godfrey \& Hassell, 1987). Most of such studies, however, are not based on life table data but on light trap sampling with considerable sampling errors, although some of the population fluctuations described in these studies were so evident as to be fully confidential 
(Wolda, 1980; 1988). Detailed population analysis based on life-table construction is necessary to identify factors involved in population fluctuations quantitatively and in particular to examine the effect of natural enemies (Bellows et al., 1992; Nakamura et al., 1990).

Nakamura and his colleagues have carried out detailed population studies on a phytophagous ladybird beetle (Nakamura et al., 1988; 1990), using the mark-recapture method in Padang, West Sumatra, climate of which is warm and rainy all the year round. According to Nakamura et al. (1988, 1990) distinct generations (on average 8 generations a year) were evident particularly in the egg stage, though some degree of overlap in adult generations also existed. They also showed that a 48-day cycle of rainfall was clearly recognized by power spectral analysis (Nakamura et al., 1990), and consequently suggested that the rainfall cycle had a relevance to shoot growth of host plants, which in turn accelerate the oviposition activities, at least to some extent. This mechanism may play a role to maintain the discreet generation in the ladybird, however, the synchronization may be apparent since substantial, though not large, differences were detected between the cycle of the rainfall and the ladybird populations. Thus, other unknown mechanisms, would operate to synchronize generation against perturbation, as adult lifespan was fairly long and overlapped (Nakamura et al., 1990).

Various hypotheses have been addressed to what mechanisms are involved in the generation-like phenomena widely observed in tropical insect populations. Corresponding data, however, are still only scarce and fragmental. In order to quantify relative contribution of various possible agents or mechanisms to population dynamics phenomena, detailed population tracking based on life table construction is indispensable (Bellows et al., 1992; Nakamura et al., 1990). In spite of such accepted recognition, detailed population studies in tropical insects, particularly inhabiting in tropical rain forests are rare, because the construction of life tables is usually laborious and difficult by practical difficulties entailed, such as high dispersal ability and/or low density of insects.

The pyrrhocorid bug Melamphaus faber studied here, is a suitable material for detailed population study, because of the sedentary habits and easiness to find by its aposematic coloration. Moreover, the population was completely isolated from adjacent populations so that mortality could be rather easily ascribed to the agents without relevance to dispersal. This study preliminary describes the population processes of male and female adults of $M$. faber.

\section{MATERALS AND METHODS}

\section{The pyrrhocorid bug, Melamphaus faber Fabricius}

The pyrrhocorid bug, Melamphaus faber (Pl. 1-a) is widely distributed in tropical rain forests in South East Asia (Miller, 1932; Kalshoven, 1981) and once was a serious pest of the Hydnocarpus trees, seed of which was the raw material for therapy oil for leprosy until the discovery of the specific remedy (Miller, 1971). The pyrrhocorid bug preferentially feeds on seeds of Hydnocarpus anthelmintica throughout all the developmental stages, probably because the outer rind of the fruits is so thin as to be less resistant to the stylets of the bug, compared with other hydnocarpus species (Miller, 1971). Females laid an egg mass, each comprising 174.44 \pm 31.07 eggs $(m \pm$ s.d., $n=48$, in 1990-91), within soil or debris beneath the ground surface, so that we found only a few egg masses in the field. Moreover, few eggs successfully hatched in the laboratory condition. Thus, we did not obtain precise data on the hatchability. The hatched nymphs spend 5 instars before molting to adult. The developmental period 

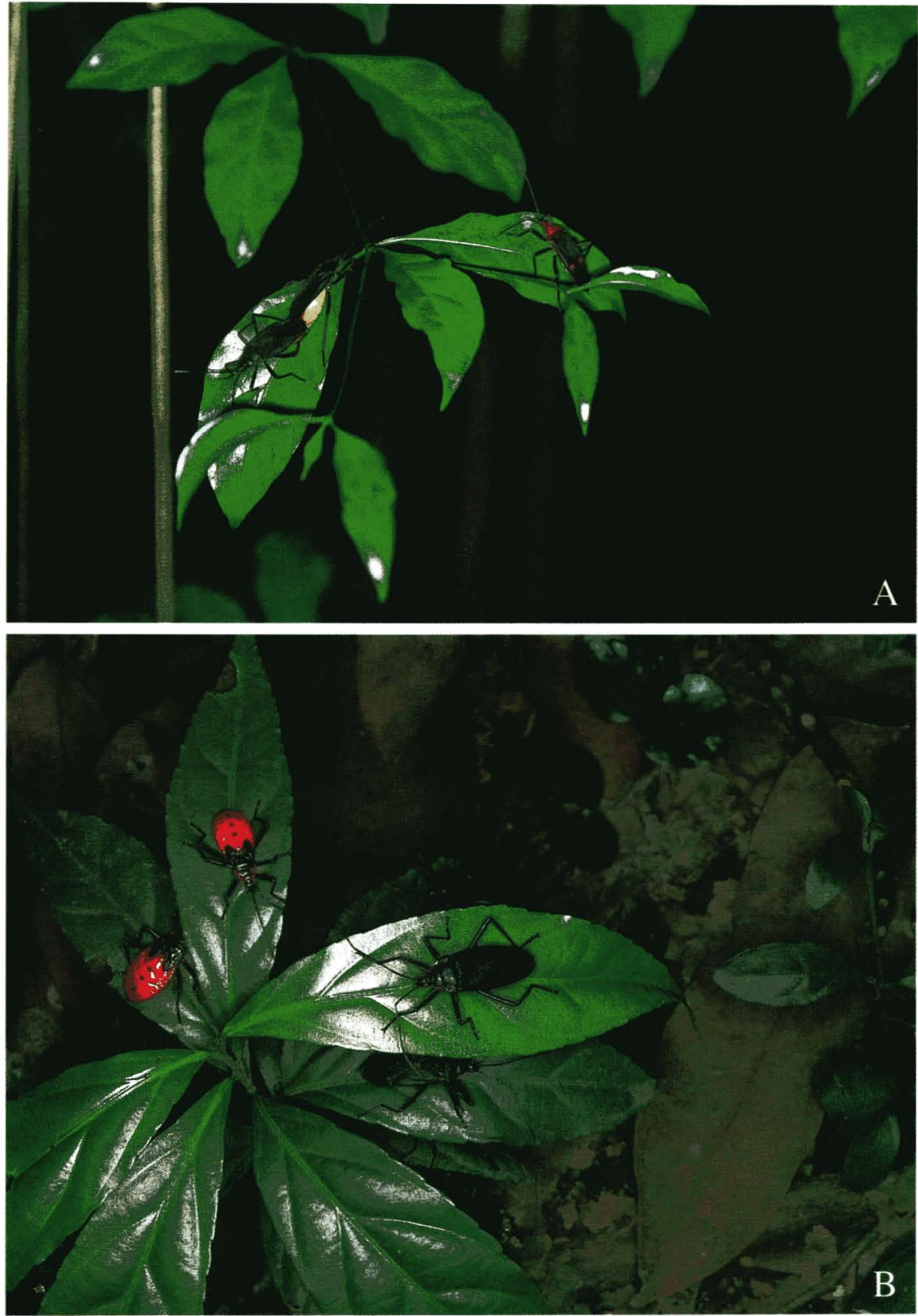

PI. 1. (a) A mating pair (left) and a newly molted adult female (right) of Melamphaus faber, the prey, resting on leaves at night, in the Bogor Botanic Gardens, Bogor, West Java, Indonesia in Nov., 1991. The adults change the body coloration ontogenically from red-black to yellowblack (see the text). (b) A newly molted adult female (right) and two 5th instar nymphs (left) of Raxa nishidai, the predator in the study site in Nov., 1998. 
of each instar under rearing condition (natural day length and room temperature) was $17.8 \pm 2.2$ days $(\mathrm{n}=26)$ for 1 st and 2 nd instar combined, $8.9 \pm 1.2(\mathrm{n}=30)$ for 3rd instar, 14.6 $\pm 2.1(\mathrm{n}=33)$ for 4th instar, and $21.5 \pm 3.8(\mathrm{n}=37)$ for 5 th instar. Fifth instar nymphs just before molting move to nearby plants where they stay until adult emergence. Teneral adults, colored in striking red and black, stay around the molting site for several days until their body become fully hardened, then move onto the ground for feeding. Within about 10 days of feeding, most adults become sexually mature and gradually darken in the body coloration, finally resulting in entire black except ventral abdomen. The pattern of change in body coloration suggests that sexually immature adults are highly conspicuous particularly against green leaves, but sexually mature adults are rather cryptic against the ground coloration. Both adult males and female feed on the ground during daytime, but move to nearby plants where they stay at night. The pyrrhocorid bug hardly fly but just walk on the ground so that the dispersal ability is extremely limited within the study area, though Miller (1932) suggested that $M$. faber moved by flight among host plant orchards in Malay peninsula. Moreover, the pyrrhocorid bug had a strong tendency to aggregate in the natal habitat rather than to disperse. All these habits made the pyrrhocorid bug a suitable material for population tracking.

The pyrrhocorid bugs usually continued genital contact for an exceptionally long period, on average about one week, maximally up to 19 days (Nishida, unpublished). This long copulation duration can be regarded as a postcopulatory mate guarding of males (Nishida, unpublished).

\section{The predatory pyrrhocorid bug, Raxa nishidai Schaefer}

Raxa nishidai (P1. 1-b) was newly described based on the specimens collected at the study area (Schaefer, 1999). R. nishidai forages only on the pyrrhocorid bug, M. faber. In the study site, no other victims other than $M$. faber have been ever found over 9 years of all the observation period, strongly indicating the predatory bug as a specialist on $M$. faber. The predator closely resembles the prey at the first sight. The apparent resemblance can be attributed to either Müllerian mimicry or aggressive mimicry (Wickler, 1968), but not to homology considering fairly large morphological differences in details between the prey and predator.

\section{The study area}

The study was carried out in the Bogor Botanic Gardens, Bogor, West Java $\left(6^{\circ} 40^{\prime} \mathrm{S}, 106^{\circ} 45^{\prime} \mathrm{E}, 280 \mathrm{~m}\right.$ above sea level), where the temperature was warm and stable all the year round (lowest in January, $25.3^{\circ} \mathrm{C}$, and highest in May and September, $\left.26.8^{\circ} \mathrm{C}\right)$ and rainfall was slightly seasonal $(3820 \mathrm{~mm} /$ year) (Nakamura et al., 1994). The study area is ca. $500 \mathrm{~m}^{2}$, located within the central part of the Bogor Botanic Gardens. The study area was completely isolated from other potential habitats since no host plant was found around the Botanic Garden, and dispersing ability of the bug was virtually limited. In the study area, Hydnocarpus anthelmintica and H. alpina, two species of host plants occur, with some other trees and shrubs some of which were used as resting or molting sites. Amongst the host plants, seeds of $H$. anthelmintica was exclusively preferred by the bug. In order to examine the amount of food resource, number and size of fallen fruits were recorded.

\section{Population census}

Population censuses were carried out 7 times intermittently over 9 years from 1990 to 1998: the first 
census from Nov. 25, 1990 - Feb. 15, 1991; the second one from Nov. 21 - Jan. 31, 1992; the 3rd one from Dec. 24, 1993 - Feb. 12, 1994; the 4th one from Aug. 24 - Sept. 20, 1994; the 5th one from Oct. 27 - Nov. 27, 1996; the 6th one from Aug. 20 - Sept. 27, 1997, and the 7th one from Aug. 23 - Sept. 29, 1998. During the first ('90-'91), 4th ('94) and 6th ('97) study periods, all the reproductive adults were marked and traced throughout the census period so that lifetime reproductive success of some marked bugs was also obtained. All the newly emerged adults were marked, by painting 4 color spots in the first study period, or individual code (in the 4th and 6th) on the ventral surface with a quick drying felt pen. For all the bugs, their location, sex, body coloration (aposematic, intermediate or cryptic), and whether in copula or not were recorded. Females cyclically ovated approximately every 10-15 days with the great distention of the abdomen, and laid maximally up to 4 egg batches during life. The cyclical changes enabled us to grade the abdomen shape into following four classes: 1; flat, 2; slightly swollen, 3; apparently swollen without distention of dorsal abdomen, and 4; maximally swollen also with distention of dorsal abdomen. These grades are defined as the ovary developmental stage, and recorded for all females found.

During the second, third, 5th and 7th study periods only casual censuses with mass-markingreobservation method were performed. In this article, we estimated density of the population in a given day for all the 7 study periods by Petersen method (Seber, 1982).

We also censused nymphs intermittently 18 times during the first study period checking the number, instar, sex, location and mortality factors to construct the life table. Some of each instar (78, 58, 85 and 125 individuals for 1st and 2nd instars combined, 3rd, 4th, and 5th instar, respectively) were mass marked and released, then were recaptured to obtain the average recapture rate(5.13, 21.26, 36.47 and $57.87 \%$ for 1 st-2nd instar combined, 3rd, 4th and 5th instars, respectively). The density of each instar was calculated as follows: total incidence of each instar found was divided by proportion of census days, recapture rate and average duration of each instar period. Except for the first study period, only 4th and 5 th instars were censused.

\section{RESULTS}

\section{Population fluctuation of M. faber}

Fig. 1 shows the population fluctuation of the adult males and females of $M$. faber in the study area intermittently from 1990 to 1998 . The density was fairly constant, considering that the study area was completely isolated from other potential habitats so that no immigration or emigration occurred. The adult density was estimated to be highest in 1998 (1609 males and 1221 females) and lowest in 1993 94 (203 males and 153 females). Among these observation periods, the 90-91, 91-91, and 93-94 periods corresponded to the rainy season, while the 94,97 , and 98 periods did to the dry season, and the 96 period did to a turn of the dry-rainy season. This indicates that the adults occur throughout year.

\section{Mortality factors}

Table 1 is the stage-specific life table of M. faber constructed in Nov. 1990 - Feb. 1991. In other study periods, we did not construct the life tables because survival processes of early instars were not censused. The largest mortality was ascribed to mortality during eggs-1st or 2nd instar, though we could not measure the hatchability of eggs directly. Instead, the hatchability was estimated by the 
Table 1. The stage-specific life table of M. faber constructed in Nov. 1990 - Feb. 1991.

\begin{tabular}{|c|c|c|c|c|}
\hline \multirow[b]{2}{*}{ Age class } & \multicolumn{3}{|c|}{ Estimated No. } & \multirow[b]{2}{*}{$\begin{array}{l}\text { Cause of Changes } \\
\text { in Number }\end{array}$} \\
\hline & $\begin{array}{l}\text { Entering Stage } \\
(\% / \% \text { survived })\end{array}$ & No. Dying & $\%$ Dying & \\
\hline Eggs & $54964(100.00)$ & 48837 & 88.85 & Unknown \\
\hline \multirow[t]{3}{*}{ 1st \&2nd Instar } & $6127(11.15)$ & 3235 & 52.80 & \\
\hline & & - & - & predation \\
\hline & & - & - & crushed by human foot \\
\hline \multirow[t]{3}{*}{ 3rd Instar } & $2892(5.26)$ & 1633 & 56.47 & \\
\hline & & 89 & 5.45 & predation \\
\hline & & 5 & 0.31 & crushed by human foot \\
\hline \multirow[t]{3}{*}{ 4th Instar } & $1259(2.29)$ & 442 & 35.11 & \\
\hline & & 222 & 50.23 & predation \\
\hline & & 18 & 4.07 & crushed by human foot \\
\hline \multirow[t]{3}{*}{ 5th Instar } & 817 (1.49) & 149 & 18.24 & \\
\hline & & 144 & 96.64 & predation \\
\hline & & 25 & 16.78 & crushed by human foot \\
\hline Adults & $668(1.22)$ & 668 & & \\
\hline
\end{tabular}

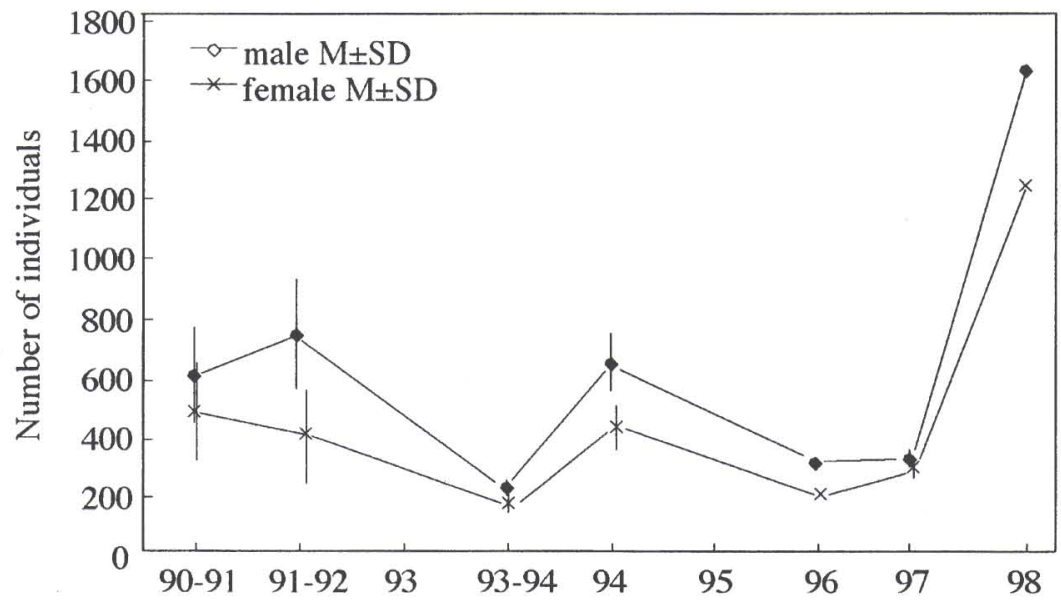

Fig. 1. Population fluctuation of adult males and adult females of Melamphaus faber in the Bogor Botanic Gardens, Bogor, West Java. The density of the bugs was estimated by Petersen method. In 1996 and 1998, the standard deviation was not shown, because the censuses was made only for four times and two times, respectively.

density of 1 st and 2 nd instar nymphs, showing that only $11 \%$ of eggs were estimated to hatch and successfully reached 1 st or 2 nd instar. Although it was difficult to estimate the density of young nymphs accurately, the discrepancy between the number of eggs laid and the number of hatched nymphs was fairly large. This leads to suggest that some critical mortality factors operated in the egg stage. During 4th and 5th instar stage, predation by $R$. nishidai played a crucial role for the mortality.

\section{Mortality agents in the adult stage}

Mortality agents in the adult stage were shown in Fig. 2. Most of the mortality factors were unknown. However, observation showed that some aged bugs seemed to be apparently physiologically 


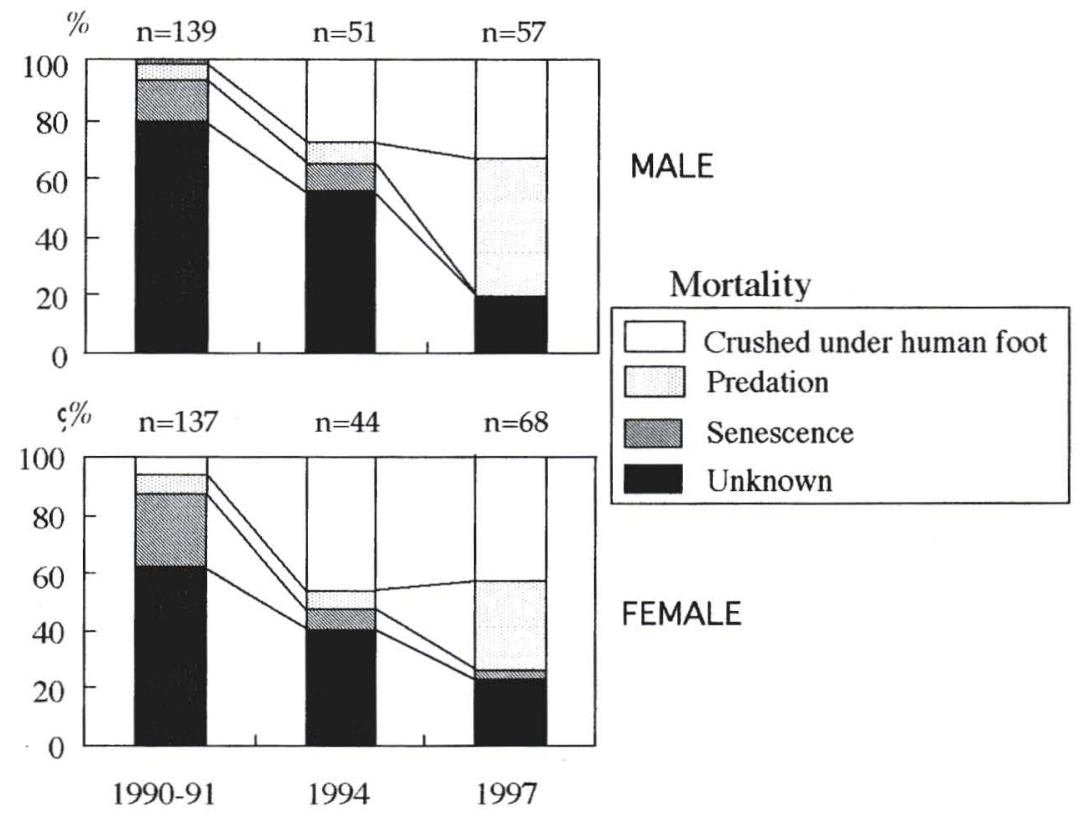

Fig. 2 Mortality factors for male and female adults of M. faber in 1990-91, 1994 and 1997.

deteriorated and close to death because they walk totteringly or hardly walk. Therefore, if found dead, those were classified as death by senescence. Senescence was rather common in 1990-91 (14\% for males and $26 \%$ for females), but was rarer in 1994 and 1997. Instead, increasing number of bugs were crushed under human foot in 1994 and 1997, because more people visited the study site on holidays in these years. Human induced mortality, however, did not seem so large, considering a large number of people walking around the study site, particularly on holidays. Casual observation revealed that $M$. faber was considerably sensitive to human approach and fled immediately, as well as to approaching predators. Other biological mortality agent ever recognized was the predation by $R$. nishidai, the species-specific predatory bug. Only 5 to $8 \%$ of mortality were ascribed to the predation in 1990-91 and 1994, since the density of the adult predators was extremely low (see the section of "The predator") and their foraging activities were more allocated toward 5th instar prey, which were more easily captured and handled. In contrast, the predation was much enhanced in 1997 (47\% for males and $31 \%$ for females) due to a rapid increase in the predator density.

The size and coloration of the predatory bug closely resembled to the prey, $M$. faber, and the predatory bug exclusively foraged on the prey, suggesting that the apparent resemblance is aggressive mimicry, though the effect of the mimesis is still vague.

\section{Survivorship curve}

Since only the limited mortality agents affected the adult population of $M$. faber, the survival rate was exceptionally high as insects (Fig. 3). Compared males with females, the survival rate was higher in males than in females in 90-91, however the tendency was obscure in 94 and 97 . Both the adult males and females spent ca. one week on a shrub or tree where they molted without feeding until the body 

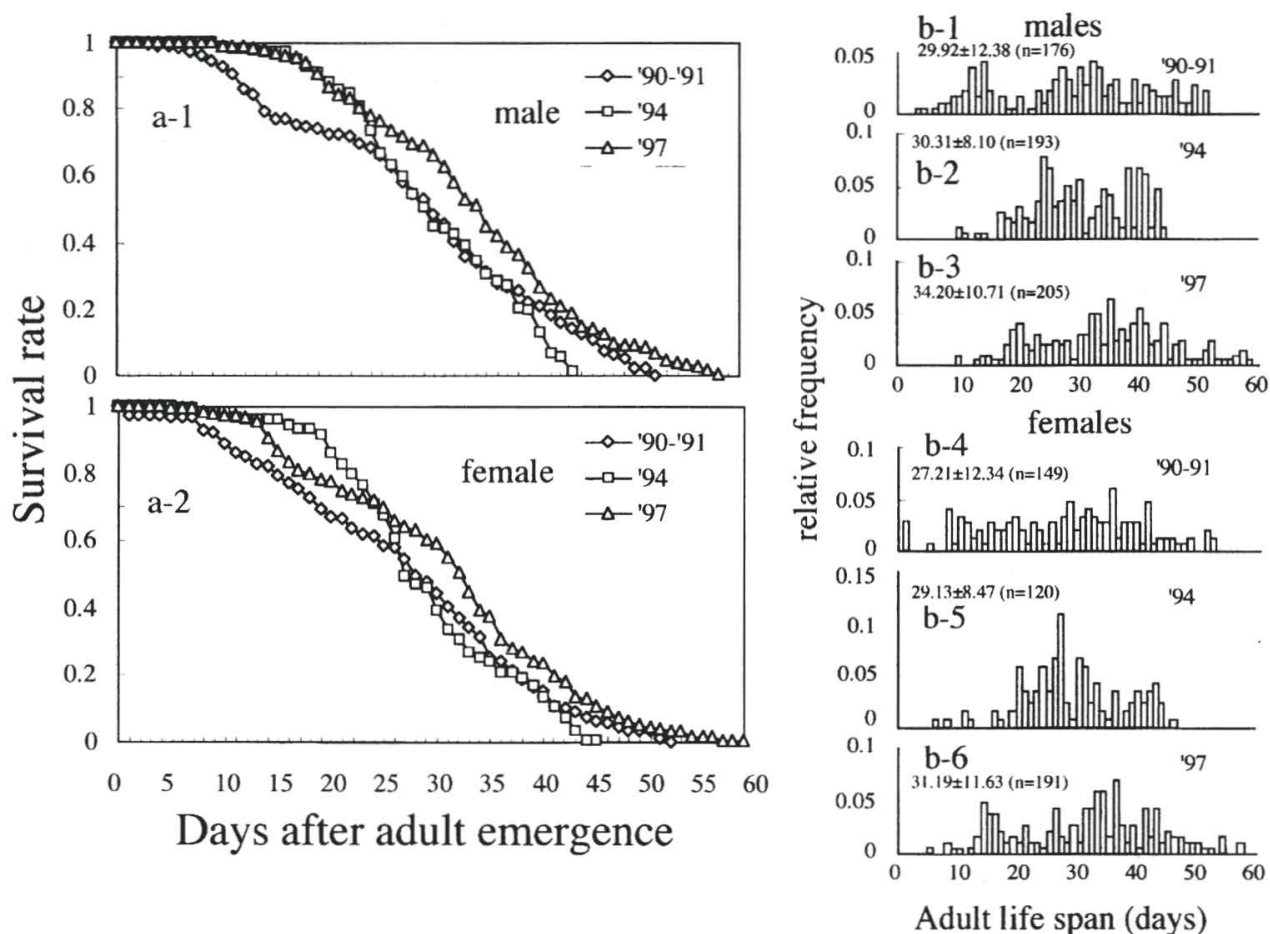

Fig. 3. Survivorship curves of adult males (a-1) and females (a-2), and abult lifespan of males (b-1, 2, and 3) and females (b-4, 5, and 6) of M. faber in 1990-91, 1994, and 1997 in the Bogor Botanic Gardensat Bogor, West Java.

fully hardened. During this period almost no males and females died. After the period, the males and females moved onto the ground, and there fed on the seeds of the host plant till sexual maturation (14.1 days for males and 11.0 days for females in 1990-91). During the pre-reproductive period mortality was fairly low and similar between males and females in each research period (e.g., the survival rates 10 days after emergence were $0.94,1.0$ and 1.0 for males, and $0.92,0.98$ and 0.98 for females in 90-91, 94, and 97, respectively). After entering the reproductive period, the male mortality was lower than the female mortality particularly in 90-91, resulting in the male-biased sex ratio in the aged cohort (e.g., the survival rates 25 days after emergence were $0.68,0.73$ and 0.77 for males, and $0.61,0.71$ and 0.72 for females in $90-91,94$, and 97 , respectively).

\section{Food resource}

Fig. 4 shows yearly changes in the food resource. As the index of the food resource level, the following three indices were shown: the number of newly fallen fruits of the host trees, the number of fallen fruits accumulated on the ground, and the number of the fruits bearing on the trees. Each of these three indices denote newly supplied resource, available resource at present, and near future resource, respectively. All the three indices showed similar fluctuation patterns. 


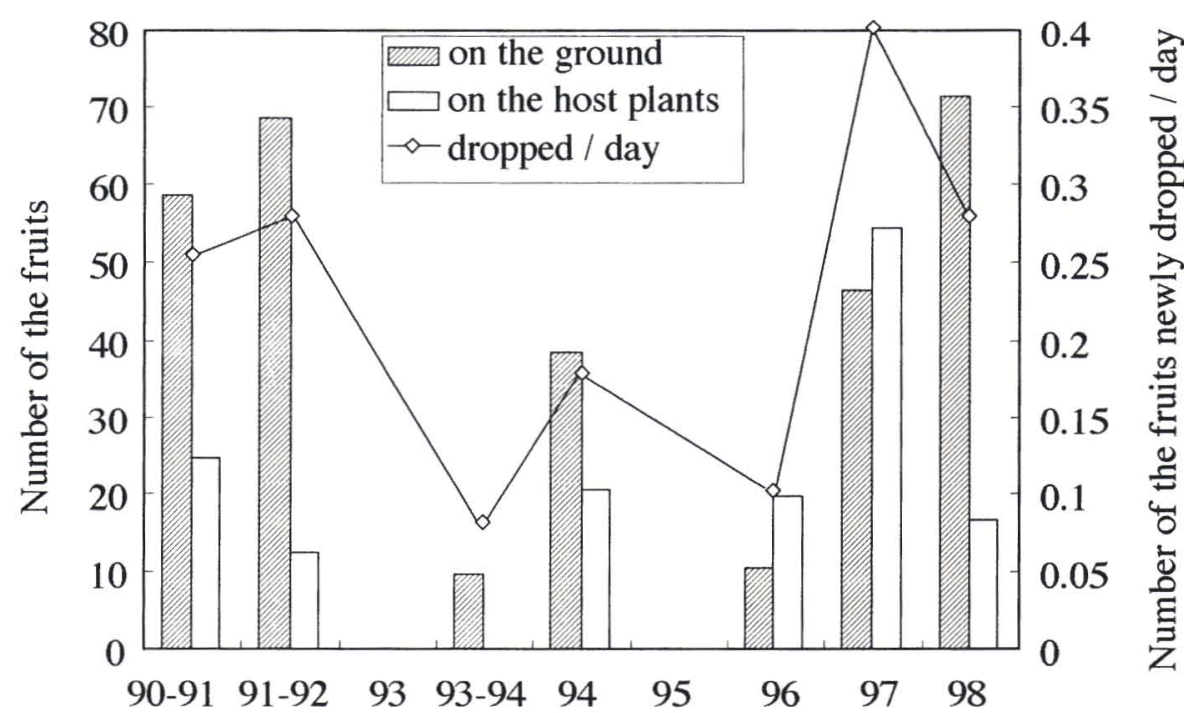

Fig. 4. Yearly changes in the food resource level. The number of the fruits (Hydnocarpus anthelmintica and $H$. alpina) accumulated on the ground (dashed bar), the number of the fruits bearing on the host plants (open bar), and average number of the fruits dropped a day (solid line).

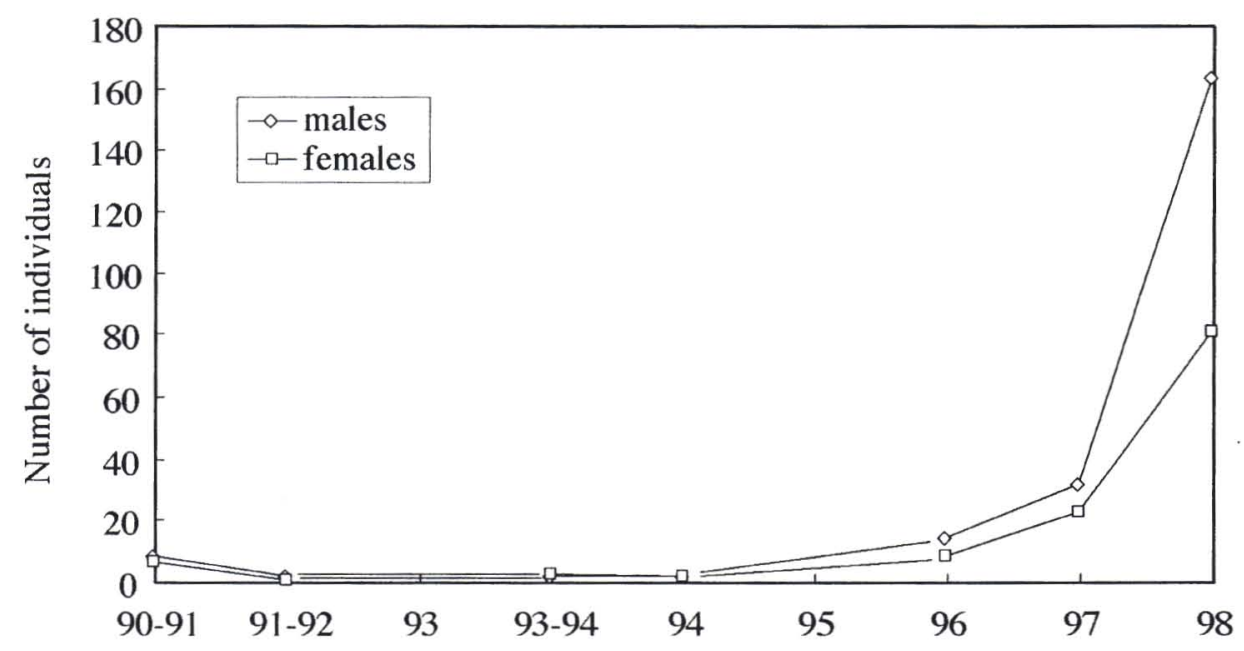

Fig. 5. Population fluctuation of the adult males and females of Raxa nishidai at the Bogor Botanic Gardens, Bogor, West Java. The density was estimated by the cumulative number of individuals marked (90-91, 94, and 96) or estimated by Petersen method utilizing mass marked individuals (9192, 93-94, 97 and 98).

\section{The predator, Raxa nishidai}

Population fluctuations of the adult males and females of the predator, $R$. nishidai were shown in Fig. 5. The density was extremely low and close to extinction during 91-94, partly because we collected all the reproductive adults ( 8 males and 6 females) at the end of the 90-91 research period. However, the 


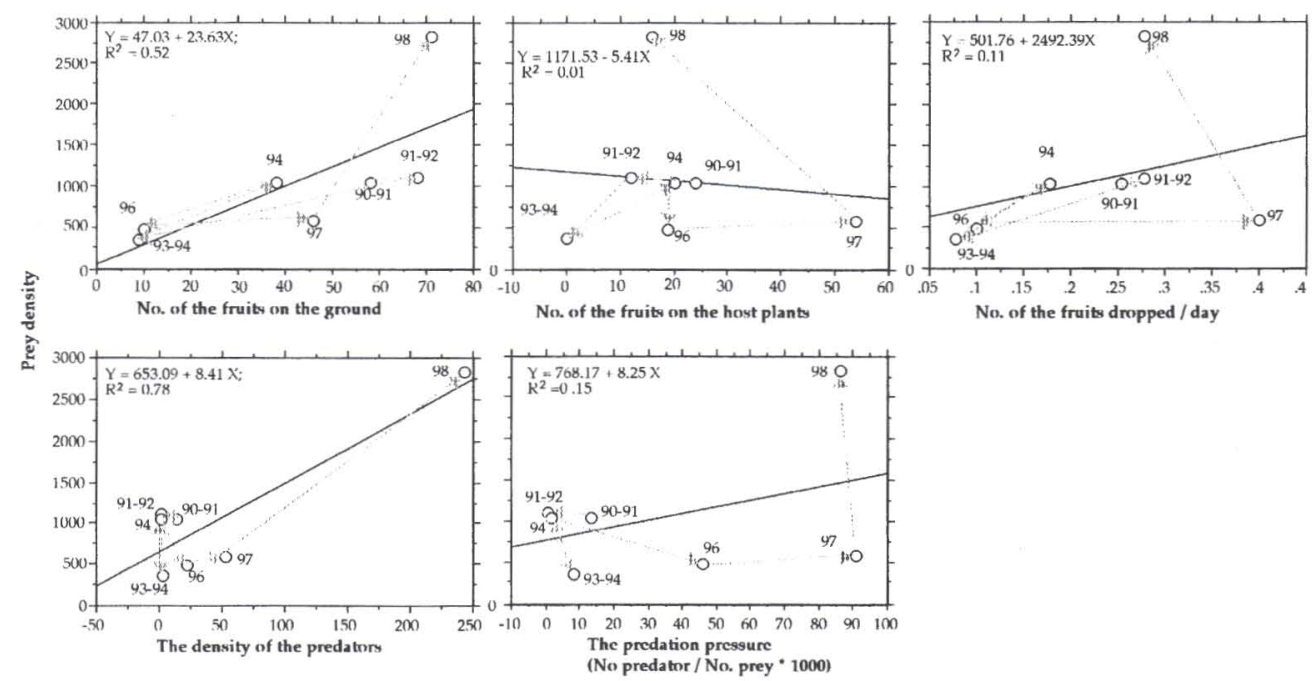

Fig. 6. Effects of the resource level and the predator density on the prey density. As the index of the resource level, the number of the fruits accumulated on the ground (upper left), the number of the fruits on the host plants (upper middle), and the average number of the fruits dropped a day (upper right) were examined. For examining the predation pressure, the prey density was plotted against the density of the predator (lower left) and the relative predation pressure (no. of the predator / no. of the prey * 1000) (lower right).

density gradually recovered and increased up to ca. 160 (males) and 80 (females) in 1998.

\section{Factors affecting the population fluctuation of $M$. faber}

Fig. 6 analyses effects of various factors potentially affecting the population fluctuation of $M$. faber. As the factors, the food resource levels (the number of the fruits accumulated on the ground, that on the trees, and that newly dropped a day) and the predation level (the density of the predator and the relative density of the predator) were examined. Of these factors, the number of the fruits accumulated on the ground fluctuated very similarly with the density of $M$. faber, suggesting that the available food resource level mostly determine population dynamics and density level of $M$. faber. In contrast, the other factors fluctuated rather differently with the density of $M$. faber, even though the correlation between the predator density and the prey density was quite high $\left(\mathrm{r}^{2}=0.782\right)$.

\section{DISCUSSION}

\section{Seasonality in population fluctuation}

Throughout the 9-years observation period both in the dry and rainy season, all the activities including mating and reproductive activities were observed. Although the observation period did not cover all the calendar months (not cover April, May, June and July), M. faber may mate and reproduce all the year round. The adult density was highest (1609 males and 1221 females) in the rainy season of 1998, and lowest (203 males and 153 females) in the rainy season of 1993-94. These results suggest that the precipitation pattern may not be critically important for determining the density level of the 
population.

According to the classification of tropical insect seasonality by Wolda (1988), the pyrrhocorid bug may be aseasonal species (type 3), which occurs more or less constantly around the year (type 3A) or occurs with unpredictable irregular variation, unrelated to seasons (type 3B). The aseasonal species comprised only $7.5 \%$ of 426 species of Homoptera, sampled by light trap over 12 years in Panama (Wolda, 1988). The present study suggests that the amount of the food resource exclusively determined the density fluctuations of $M$. faber. The effect of predation on the population dynamics seemed to be miner, though still vague. Further study on long-term dynamics is required to draw conclusion in order to unveil underpinning mechanisms behind the aseasonal density fluctuation of $M$. faber.

\section{Mortality factors}

Of all the life stages the largest mortality was due to mortality in egg stage. It is still unknown what mortality factors were involved in such high egg mortality. Even under laboratory conditions hatchability of eggs were extremely low (only two eggs hatched among 3858 eggs examined, Nishida unpublished), as was also suggested by Miller (1932), so that whether the eggs were really fertilized should be examined. The smallest population density was less than five hundred, moreover, the population was completely isolated from adjacent populations because of poor flight ability and habitat fragmentation. These results may suggest a small effective size of population and resultant effect of inbreeding depression. It is yet unknown to what extent inbreeding occurs. However, as previously referred, low hatchability of eggs was also reported in a Malaysian population in which dispersal was commonly observed (Miller, 1932). Further examination is necessary to specify the mortality agent in the egg stage.

No parasitoids were observed, though Miller (1932) reported a tachinid fly parasitizing $M$. faber in a Malaysian population.

\section{Prey-Predator interaction}

Except the egg stage, predation by $R$. nishidai which was extremely specialized to feed on M. faber, was the largest mortality agent. Predation was most intense particularly on the 5 th instar, because both adults and 5th instar of $R$. nishidai preferentially fed on 5th instar of the prey. The density of the predator population was always extremely low. Bogor Zoological Museum preserved one female specimen of $R$. nishidai among many specimens of $M$. faber, both of which were collected on Aug. 20, 1975 in the Bogor Botanic Garden, suggesting that the population of the predatory bug had persisted at least for these 24 years. It was surprising that the predator population persisted for a long period at least 24 years, even though the predator has following characteristics usually being regarded as disadvantageous for population persistence: the extremely low density, strong philopatry without dispersal partly due to poor flight ability, monophagy, and isolation from other potential habitats. According to the accepted view of population extinction, small population size itself tends to lead extinction through demographic and environmental stochasticity, and genetic deterioration by inbreeding (Lawton, 1995). What factors have been involved in the persistence of the $M$. faber and $R$. nishidai population? Extreme high survivorship of the adults and low reproductive ability were observed both in the predator and the prey (Nishida, unpublished), which may contribute the 
persistence. In addition, the poisonous and aposematic traits have enabled the prey population to escape from would-be predators, and further have protected the mimetic predator from potential mortality agents. These ecological characteristics might not be rare in persistent insect species with extremely low densities, which are inhabiting in tropical rain forests with the largest biological diversity.

ACKNOWLEDGMENTS We express sincere thanks to Dr. Soetikno Wiryoatomodjo (Director of Pusilitbang Biologi, LIPI) and Mr. Mohammad Amir (Director, Balitbang Zoologi, Psilitbang Biologi, LIPI) for their generous support during the research in Indonesia. Thanks are also due to Dr. N. Kamata of Kanazawa University for his critical reading of the manuscript. This study was carried out with the permission of Lembaga Ilmu Pengetahuan Indonesia (LIPI), and was supported partly by Grant-in Aid for the International Scientific Research Program of the Ministry of Education, Science and Culture of Japan.

\section{REFERENCES}

Bellow, Jr., T. S., Driesche, R. G. van \& Elkinton, J. S. E. 1992. Life-table construction and analysis in the evaluation of natural enemies. Ann. Rev. Entomol., 37: 587-614.

Fincke, O. M., 1988. Sources of variation in lifetime reproductive success in a nonterritorial damselfly (Odonata: Coenagrionidae). In: Clutton-Brock, T. H. (ed.) Reproductive Success, 24-43. University of Chicago Press, Chicago.

Godfrey, H. C. J. \& Hassell, M. 1987. Natural enemies may be a cause of discrete generations in tropical insects. Nature 327: 144-147.

Kalshoven, L .G. E., 1981. Pest of Crops in Indonesia. (P.A. van der Laan, rev. and transl.). P. T. Ichtiar Baru-Van Hoeve, Jakarta.

Lawton, J. H., 1985. Population dynamic principles. In: Lawton, J. H. \& May, R. M. (eds.) Extinction Rates. Oxford University Press, Oxford.

Miller, N. C. E., 1932. Observations on Melamphaus faber, F. (Hem., Pyrrhocoridae) and descriptions of early stages. Bull. ent. Res. 23: 195-201.

, 1971. The Biology of Heteroptera. 2nd edition. E. W. Classey, Hampton.

Nakamura, K., Abbas, I. \& Hasyim, A. 1988. Population dynamics of the phytophagous lady beetle, Epilachna vigintioctopunctata, in an eggplant field in Sumatra. Res. Popul. Ecol. 30: 25-41.

- - $\&-1990$. Seasonal fluctuations of the ladybird beetle, Epilachna vigintioctopunctata (Coccinellidae: Epilachninae) in Sumatra and comparisons to other tropical insect population cycles. In R. Ohgushi, S. F. Sakagami \& D. W. Roubik (eds.) Natural History of Social Wasps and Bees in Equatorial Sumatra., 13-29. Hokkaido University Press, Sapporo.

— Noerdjito, Woro A. \& Hasyim, A. 1994. Regional difference and seasonality of rainfall in Java, with special reference to Bogor. Tropics 4: 93-103.

Nishida, T., 1987. Measurement of the opportunity for natural and sexual selection in a breeding population of the coreid bug (Colpula lativentris). Res. Popul. Ecol. 29: 271-289.

, 1994. Spatio-temporal variation of natural and sexual selection in breeding populations of the coreid bug, Colpula lativentris (Heteroptera: Coreidae). Res. Popul. Ecol. 36: 209-218. 
Partridge, L. \& Farquhar, M. 1981. Sexual activity reduces lifespan of male fruitflies. Nature 294: 580-582.

Rose, M. R. 1991. Evolutionary Biology of Aging. Oxford University Press, New York.

Schaefer, C. W. 1999. Review of Raxa (Homoptera: Pyrrhocoridae). Ann. Ent. Soc. Am. 92: 14-19.

Seber, G. A. F. 1982. The Estimation of Animal Abundance and Related Parameters (2nd. ed.), Griffin, London.

Wickler, W, 1968. Mimicry in Plants and Animals. World University Library, London.

Wolda, H. 1980. Seasonality of tropical insects. I. Leafhoppers (Homoptera) in Las Cumbres, Panama. J. Anim. Ecol. 49: 277-290.

_ 1988. Insect seasonality: why? Ann. Rev. Ecol. Syst. 19: 1-18.

Young, A. E., 1982. Population Biology of Tropical Insects. Plenum, New York.

Received March 25, 1999

Accepted March 20, 2000

\section{西田隆義，中村浩二，Woro N. NOERDJTOインドネシア西ジャワ州ボゴール植物 園におけるダイフウシホシカメムシとその種特異的捕食者の個体群動態}

インドネシア西ジャワ州にあるボゴール植物園にはイイギリ科の果実を専食するダイフウシホシカメムシ (Melamphaus faber) とさらにこれを専食するニシダホシカメムシ (Raxa nishidai) の孤立個体群が存在する。 両種の個体群を1990年から1998年にかけての9年間，断続的に追跡した。両種ともに，雨期・乾期にかかわ らず常に繁殖活動を行っていた。ダイフウシホシカメムシの個体群密度は孤立個体群にもかかわらずかな り安定しており,一方二シダホシカメムシは非常な低密度にも関わらず調査期間中存続した。両種ともに 移動能力はきわめて低く, かつ孤立個体群であったため移出や移入はないものと考えられた。ダイフウシ ホシカメムシ個体群の変動パタンは䬣資源の変動パタンと非常にうまく同調していたが, 一方, 捕食者で あるニシダホシカメムシはダイフウシホシカメムシの個体群動態にあまり影響を与えてはいなかった。す なわち, ダイフウシホシカメムシ個体群の変動は主に䬣資源の変動によって規定されているものと考えら れた。餌資源であるイイギリ科の種子の生産量は年により大きく変動したが，ダイフウシホシカメムシが 実際に利用する地上に蓄積した種子量は比較的安定しており，これがダイフウシホシカメムシの個体群動 態が安定している理由の一つと考えられた。 